\title{
The relationship of daily sperm production with number of Sertoli cells and testicular size in adult horses: role of primitive spermatogonia
}

\author{
L. Johnson ${ }^{1}$, G. K. Carter ${ }^{2}$, D. D. Varner ${ }^{2}$, T. S. Taylor ${ }^{2}$, \\ T. L. Blanchard ${ }^{2}$ and M. S. Rembert ${ }^{1}$ \\ ${ }^{1}$ Department of Veterinary Anatomy and Public Health and; ${ }^{2}$ Department of Large Animal \\ Medicine and Surgery, College of Veterinary Medicine, Institute for Equine Science and \\ Technology, Texas Agricultural Experiment Station, Texas A\&M University, College Station, \\ TX 77843, USA
}

\begin{abstract}
The number of Sertoli cells is important in spermatogenesis as noted by significant correlations between the number of Sertoli cells and the number of germ cells observed as early as type $B_{2}$ spermatogonia in the horse. However, the stage within spermatocytogenesis at which these relationships first occur is unclear. The relationships between the number of Sertoli cells and parenchymal weight and the number of germ cells during the mitosis of spermatogenesis were determined in 184 adult horses to identify the developmental stage (that is, the earliest germ cell) at which significant relationships are established. The total numbers of all types of $A$ spermatogonia and of specific subtypes $\left(A_{1}, A_{2}, A_{3}, B_{1}\right.$ or $\mathrm{B}_{2}$ ) of spermatogonia were correlated with the number of Sertoli cells and with parenchymal weight. The number of each cell type was calculated using stereology. The number of Sertoli cells was correlated $(P<0.01)$ with parenchymal weight $(r=0.85)$ and with daily sperm production $(r=0.83)$, and parenchymal weight was correlated $(P<0.01)$ with daily sperm production $(r=0.89)$. The number of Sertoli cells was correlated $(P<0.01)$ with the number of type $\mathrm{A}(r=0.81)$ and $\mathrm{A}_{1}(r=0.74)$ spermatogonia. Parenchymal weight was correlated with the number of type $A(r=0.80)$ spermatogonia and with the number of $\mathrm{A}_{1}(r=0.67)$ spermatogonia. These data are consistent with the hypotheses that the number of Sertoli cells is important in determining testicular size and daily sperm production and that the relationship of daily sperm production to the number of Sertoli cells or to parenchymal weight has already been established at the level of primitive spermatogonia.
\end{abstract}

\section{Introduction}

Recent studies of one- to five-year-old stallions (Johnson et al., 1991 ) showed significant $(P<0.01)$ correlations between daily sperm production per horse and number of Sertoli cells per horse $(r=0.80)$, between daily sperm production per horse and paired testicular parenchymal weight $(r=0.94)$, and between number of Sertoli cells per horse and paired parenchymal weight $(r=0.85)$. In horses of mixed ages (mostly $\leqslant 5$ years old), Berndtson and Jones (1989) reported significant correlations between the relative number of Sertoli cells and numbers of various populations of germ cells. In adult horses (more than four years old), the number of Sertoli cells per testis was positively correlated significantly $(P<0.01)$ with the numbers per testis of round spermatids $(r=0.65)$, late primary spermatocytes $(r=0.70)$, early primary spermatocytes $(r=0.67)$, and type $\mathrm{B}_{2}$ spermatogonia $(r=0.63)$ (Johnson and Tatum, 1989). In this study, testicular parenchymal weight was related to the number of Sertoli cells $(r=0.81 ; P<0.01)$ and the number of $\mathrm{A}$ spermatogonia $(r=0.75 ; P<0.01)$. However, little attention has been directed to determining the earliest spermatogonial subtype in spermatogenesis, the number of which is significantly related to the number of Sertoli cells or to testicular size. Identification of the type of spermatogonial cell in spermatogenesis, the number of which first exhibits a significant relationship with the number of Sertoli cells or with parenchymal weight, will direct further research to enhance spermatogenesis and eliminate seasonality in horses to that developmental step in spermatogenesis.

To determine the cell type, the number of which first exhibits a significant relationship with number of Sertoli cells or testicular size, the total number of all types of $A$ spermatogonia or the number of specific subtypes $\left(A_{1}, A_{2}, A_{3}, B_{1}\right.$ or $\left.B_{2}\right)$ of spermatogonia was correlated with the number of Sertoli cells and paired parenchymal weight in a large number of adult horses. The seasonal variation in testicular weight, daily sperm production (Johnson and Neaves, 1981; Amann, 1989; Johnson, 1991b), and number of Sertoli cells (Johnson and Thompson, 
1983; Johnson and Nguyen, 1986; Johnson, 1986; Johnson and Tatum, 1989; Johnson et al., 1991a, b) allowed the relationship between Sertoli cells and daily sperm production, previously traced back to type $B_{2}$ spermatogonia (Johnson and Tatum, 1989) to be determined. It was found that the relationship was already established at the developmental step of the most primitive $\left(A_{1}\right)$ spermatogonia.

\section{Methods}

\section{Animals and Tissues}

Testes from 184 adult horses (more than 4 years old) were obtained throughout one year from an abattoir and fixed by vascular perfusion with $2 \%$ glutaraldehyde (Sigma, St Louis, $\mathrm{MO}$ ) in $0.1 \mathrm{~mol}$ sodium cacodylate buffer $\mathrm{l}^{-1}$. Only horses of light-weight breed, in good body condition, and with a smooth hair coat were used. Ages were determined from eruption and wear of the incisors. Five randomly selected pieces of testicular tissue ( $10 \mathrm{~mm} \times 5 \mathrm{~mm} \times 2 \mathrm{~mm}$ ) were further fixed in osmium tetroxide, embedded in Epon 812, sectioned at $0.5 \mu \mathrm{m}$, stained with toluidine blue, and observed by bright field microscopy. Stereological evaluation of nuclei of Sertoli cells, spermatogonia and spermatids was conducted as described for these same horses by Johnson and Tatum (1989) and Johnson (1991a). From a subset of adult horses $(n=9 ; 9.1 \pm 1.0$ years old; specimens obtained in December and $n=10 ; 11.7 \pm 2.1$ years old; specimens obtained in June), other large pieces of fixed testicular tissue $(10 \mathrm{~mm} \times 20 \mathrm{~mm} \times 5 \mathrm{~mm})$ were embedded in methacrylate, sectioned at $5.0 \mu \mathrm{m}$, stained with toluidine blue, and observed by bright field microscopy to determine the percentage of each subtype of spermatogonia. When distinction among the subtypes of spermatogonia was needed, as in the subset of horses above, it was necessary to use thicker sections $(5.0 \mu \mathrm{m}$ methacrylate), which revealed subtle differences in nuclear chromatin profiles that were not seen in thinner Epon sections. Details of nuclear profiles for these five spermatogonial subtypes in the horse and their appearance in seminiferous epithelium in different spermatogenic stages were described by Johnson (1991a). The subset was limited to 19 horses owing to labour intensity of these measurements.

\section{Stereology and calculation of number of germ cells}

The total number of $A$ plus $B_{1}$ spermatogonia $\left(A_{1}, A_{2}, A_{3}\right.$ and $B_{1}$ spermatogonia combined), $B_{2}$ spermatogonia, or early (preleptotene, leptotene and zygotene) primary spermatocytes were determined by stereology of Epon sections on the basis of nuclear volume density, parenchymal volume and volume of a single nucleus for each cell type (Johnson, 1985; Johnson and Tatum, 1989). Shrinkage of equine tissues fixed with glutaraldehyde and then with osmium tetroxide before subsequent Epon embedding was determined by Johnson and Neaves (1981) to be negligible. Stereologic procedures included the point-counting method of Chalkley (1943) of $0.5 \mu \mathrm{m}$ sections to determine the nuclear volume density (percentage of the parenchyma occupied by nuclei of each type of cell). Nuclear volume of individual cells was determined in $20 \mu \mathrm{m}$ Epon sections by the measurement of the maximum nuclear diameter and the formula for the volume of a sphere (Johnson and Neaves, 1981). Since season does not alter $(P>0.05)$ the nuclear diameter of germ cells with spherical nuclei $\left(A+B_{1}\right.$ spermatogonia $(6.8 \pm 0.1$ versus $6.9 \pm 0.1 \mu \mathrm{m})$ in winter and summer, respectively), $B_{2}$ spermatogonia $(6.5 \pm 0.1$ versus $6.4 \pm 0.1 \mu \mathrm{m})$, and early primary spermatocytes (8.8 \pm 0.1 versus $8.0 \pm 1 \mu \mathrm{m})$ in the stallion, these nuclear volumes were not influenced by season (Johnson, 1985). Likewise, the volume of a single Sertoli cell nucleus in the winter $(678 \pm 71 \mathrm{fl})$ was similar $(P>0.05)$ to that in the summer $(693 \pm 38 \mathrm{fl}$; Johnson and Nguyen, 1986; Johnson and Thompson, 1986). The number of a given cell type was determined by dividing the product of the nuclear volume density, parenchymal volume and a histological correction factor for section thickness and nuclear diameter (Weibel and Paumgartner, 1978) by the volume of a single nucleus of that cell type (Johnson and Neaves, 1981).

At each stage of the spermatogenic cycle (Swierstra ef al., 1974), the number of each subtype of spermatogonia $\left(A_{1}, A_{2}\right.$, $A_{3}$ or $B_{1}$ ) was counted per 100 Sertoli cells in methacrylate sections to determine the percentage of each subtype in the total population of $A$ and $B_{1}$ spermatogonia for each of the 19 horses in the subset (Johnson, 1991a). The number of a given spermatogonial subtype was calculated by multiplying the percentage of that subtype of spermatogonia (for a given horse) by 100 and by the total number of $A$ plus $B_{1}$ spermatogonia for that horse.

\section{Statistical analysis}

The relationship between paired dependent variables was determined by simple regression analysis (Sokal and Rohlf, 1969). Correlation coefficients between paired variables were tested for level of significance (Sokal and Rohlf, 1969).

\section{Results}

The number of Sertoli cells per horse and paired parenchymal weight were highly correlated with daily sperm production per horse (Fig. 1a, b). Likewise, paired parenchymal weight and number of Sertoli cells per horse were significantly correlated with the number of $A$ plus $B_{1}$ spermatogonia per horse (Fig. 1c, d). The number of Sertoli cells per horse was correlated $(r=0.85 ; P<0.01)$ with testicular size as measured by paired parenchymal weight.

In a subset of 19 horses representing both winter and summer seasons, a similar relationship was found; however, the relationship was traced back further in spermatogenesis to primitive spermatogonia. The number of Sertoli cells per horse was significantly correlated with daily sperm production per horse, number of $A$ plus $B_{1}$ spermatogonia, and number of each subtype of spermatogonia and early primary spermatocytes (Fig. 2). In the same subset of horses, paired parenchymal weight was significantly $(P<0.01)$ correlated with daily sperm production, number of $A$ plus $B_{1}$ spermatogonia, and each subtype of spermatogonia (except $A_{2}$ spermatogonia) and young primary spermatocytes (Fig. 3). For correlation of the number of $A_{2}$ spermatogonia with either number of Sertoli cells 
(a)

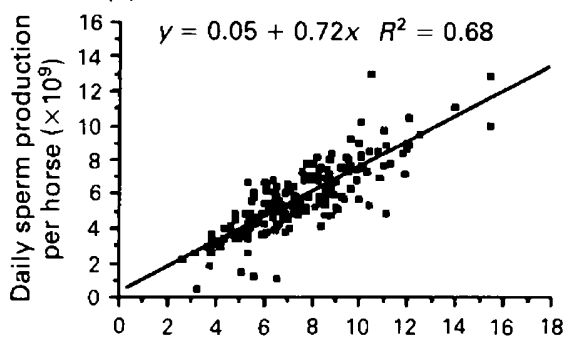

Number of Sertoli cells per horse $\left(\times 10^{9}\right)$

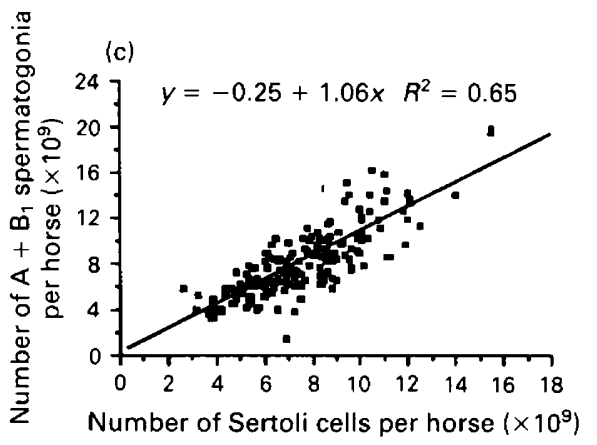

(b)

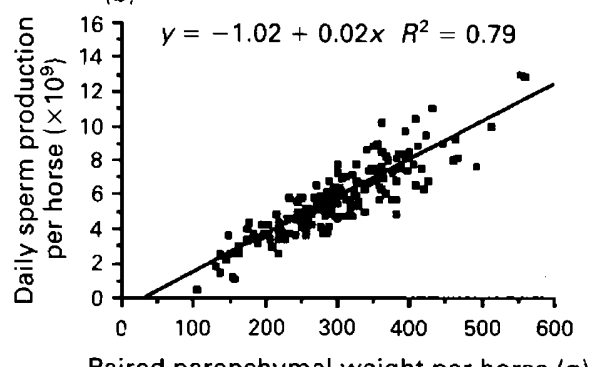

Paired parenchymal weight per horse (g)

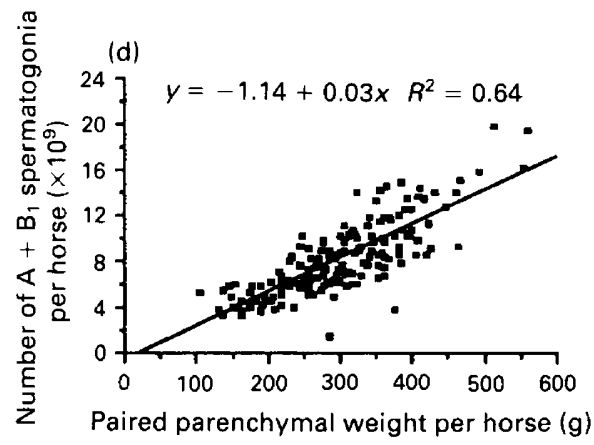

Fig. 1. The effect of the number of Sertoli cells and parenchymal weight on daily sperm production and number of the combination of all $A$ plus $B_{1}$ spermatogonia in 184 adult horses (more than 4 years old) whose testes were obtained throughout the year. All correlation coefficients ((a) $r=0.827$, (b) $r=0.887$, (c) $r=0.806$, and (d) $r=0.802)$ are significant $(P<0.01$ ). (a) Variation in the number of Sertoli cells per horse accounts for $68 \%$ of the variation in daily sperm production per horse and (c) $65 \%$ of the variation in number of $A$ plus $B_{1}$ spermatogonia per horse. Variation in parenchymal weight per horse accounts for (b) $79 \%$ of the variation in daily sperm production and (d) $64 \%$ of the variation in number of $A$ plus $B_{1}$ spermatogonia.

or paired parenchymal weight, the correlation coefficient was lower $(P<0.05$ or nonsignificant, respectively) than for all other types of germ cell $(P<0.01)$.

\section{Discussion}

Two notes of caution are considered important with our findings. First, correlation tends to be higher when common factors are involved. Parenchymal weight for a given horse was a common factor in estimates of all cell populations, including germ cells and Sertoli cells. However, parenchymal weight (126 $\pm 6 \mathrm{~g}$ in the non-breeding versus $163 \pm 7 \mathrm{~g}$ in the breeding season; $P<0.01$ ) is a major factor in seasonal variation in the number of testicular cells (Johnson, 1991a). Second, the underlying cause for the relationship between cell population sizes cannot be determined from correlations. Indeed, the underlying cause may be factors (for example hormones, growth factors or mitogens; Bardin, 1988) that stimulate both spermatogonia and the number of Sertoli cells or parenchymal weight to keep their population size parallel even when season effects for each of these variables are known (Johnson, 1991a, b). However, Sertoli cell mitogens (Feig et al., 1980) may be important in a paracrine or autocrine fashion.

Seasonally, stallions modulate or regulate spermatogenesis by altering both the number of primitive spermatogonia and the yield of early spermatogonial subtypes (Johnson, 1991a), but they continue to produce spermatozoa throughout the year (Thompson et al., 1977; Johnson and Thompson, 1983). The effect of season on spermatogenesis is a function of germ cell degeneration during meiosis and seasonal modulation of the number of $A$ plus $B_{1}$ spermatogonia (Johnson, 1991b). The number of $A$ plus $B_{1}$ spermatogonia in the breeding season was twice that in the nonbreeding season (Johnson, 1985).

Although previous study of these horses revealed seasonal variation in the numbers of different subtypes of spermatogonia (Johnson, 1991a), the current study reveals that seasonal changes in the number of these spermatogonial subtypes parallel changes in the number of Sertoli cells per horse and in testicular size (paired parenchymal weight). On the basis of a subset of 19 horses representing both seasons and in which the number of each subtype of spermatogonia was determined, significant correlations were found between the number of Sertoli cells and each subtype of spermatogonia including the most primitive, $A_{1}$ spermatogonia. The variation in number of Sertoli cells in these adult horses in both seasons that could be explained by variation in number of each subtype of spermatogonia ranged from 25 to $60 \%$. Paired parenchymal weight was significantly correlated with number of each subtype of spermatogonia except $A_{2}$. Variation in the number of each subtype of spermatogonia accounted for $18-71 \%$ of the variation in paired parenchymal weight. Variation in number of the most primitive (type $A_{1}$ ) spermatogonia accounted for 55 and $46 \%$ of variation in number of Sertoli cells and 
(a)

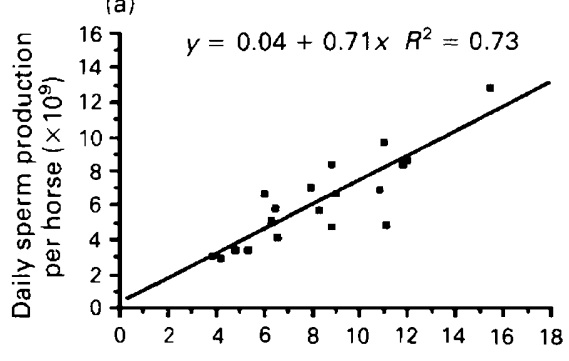

Number of Sertoli cells per horse $\left\{10^{9}\right\}$

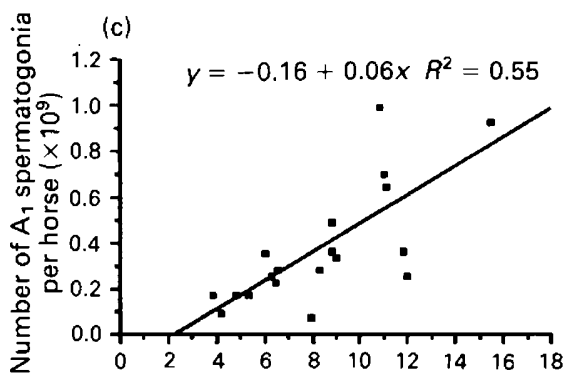

Number of Sertoli cells per horse $\left(10^{9}\right)$

(e)

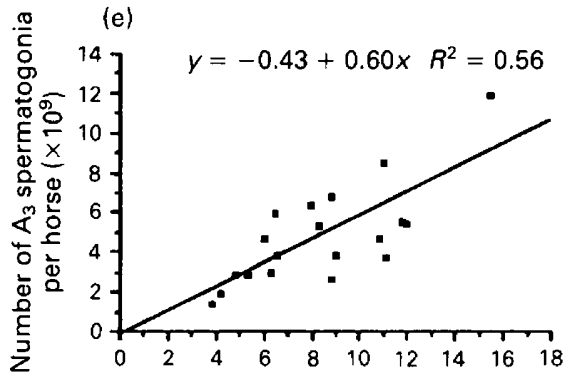

Number of Sertoli cells per horse $\left(10^{9}\right)$

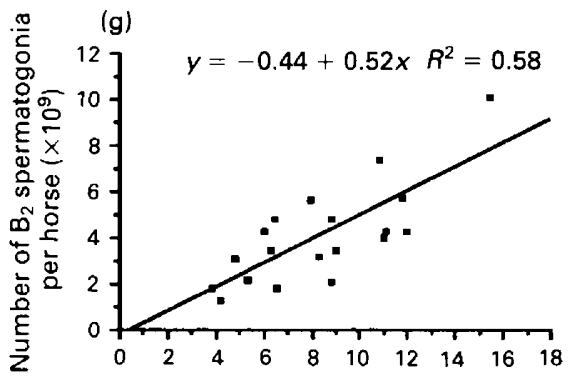

Number of Sertoli cells per horse $\left(10^{9}\right)$
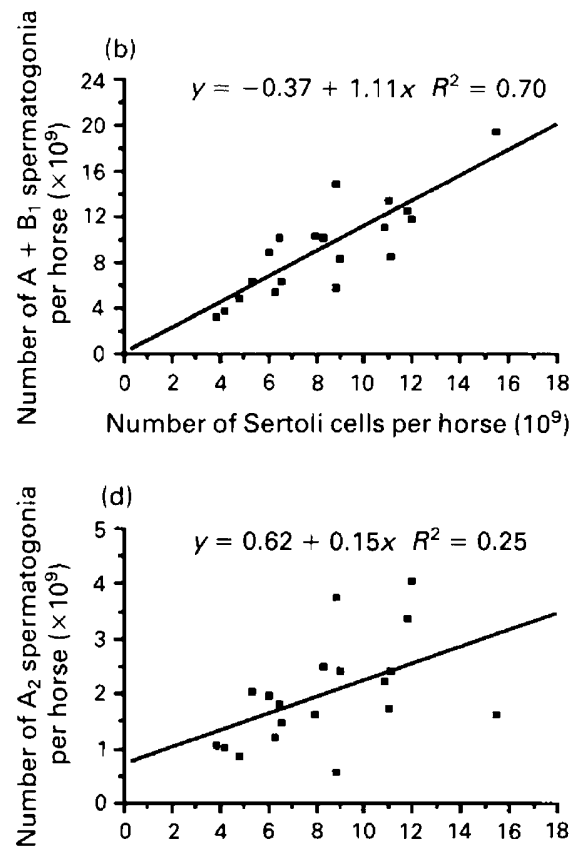

Number of Sertoli cells per horse $\left(10^{9}\right)$

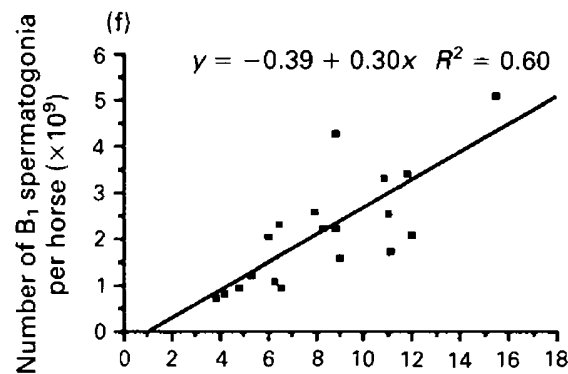

Number of Sertoli cells per horse $\left(10^{9}\right)$

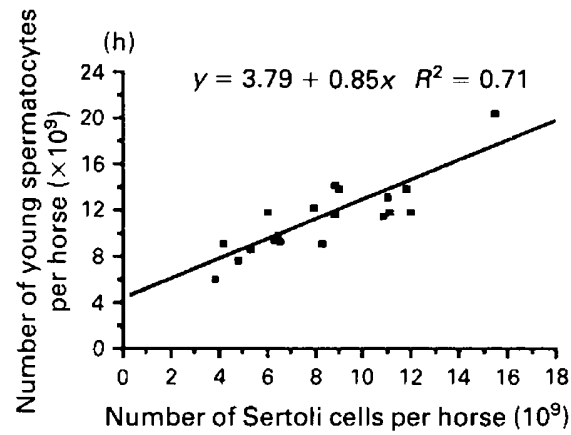

Fig. 2. The effect of number of Sertoli cells per horse in a subset of 19 horses representing both the breeding (June) and nonbreeding (December) seasons on (a) daily sperm production per horse and on the number per horse of (b) all $A$ plus $B_{1}$ spermatogonia, (c) $A_{1}$ spermatogonia, (d) $A_{2}$ spermatogonia, (e) $A_{3}$ spermatogonia, (f) $B_{1}$ spermatogonia, (g) $B_{2}$ spermatogonia and (h) young primary spermatocytes. The $R^{2}$ value on each graph reveals the percentage of the variation in number of Sertoli cells that is attributed to variation in daily sperm production or number of each germ cell. Correlation coefficients: ((a) $r=0.856$, (b) $r=0.834$, (c) $r=0.744$, (e) $r=0.748$, (f) $r=0.776$, (g) $r=0.763$ and (h) $r=0.845$ ) are significant $(P<0.01$ ) and the correlation coefficient between (d) number of Sertoli cells and number of $A_{2}$ spermatogonia is significant $(P<0.05)$.

parenchymal weight, respectively. As a general rule, the correlation coefficients were lower as the germ cell types occurred earlier in spermatocytogenesis. The percentage of variation in the correlation that is not explained is sufficient to account for the seasonal variation in germ cell ratios during spermatocytogenesis reported by Johnson (1991a). 
(a)

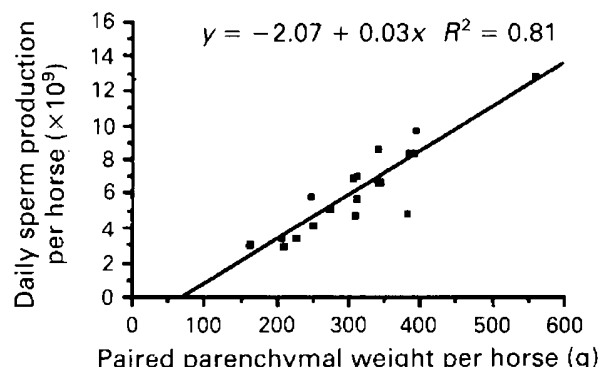

(c)

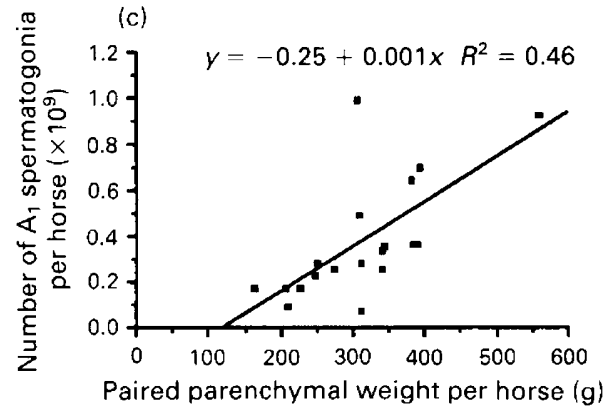

(e)
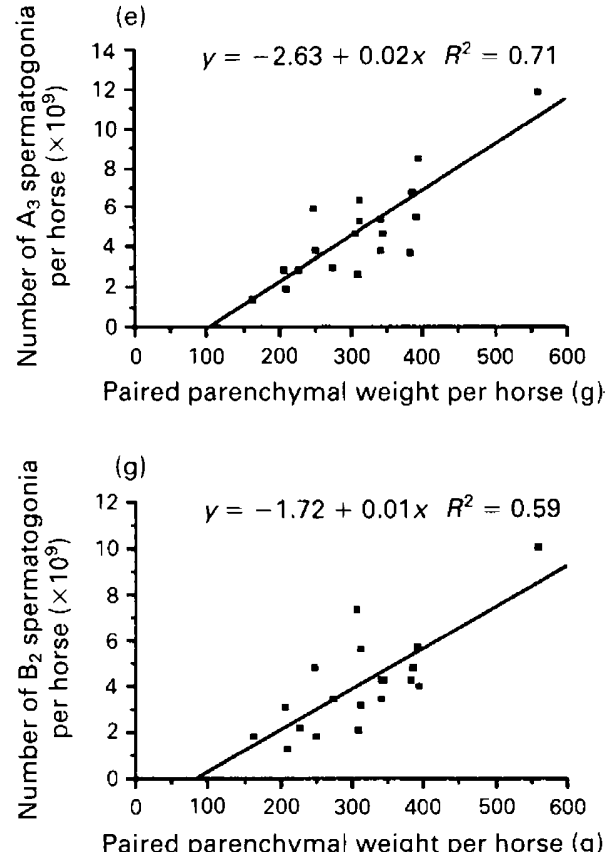
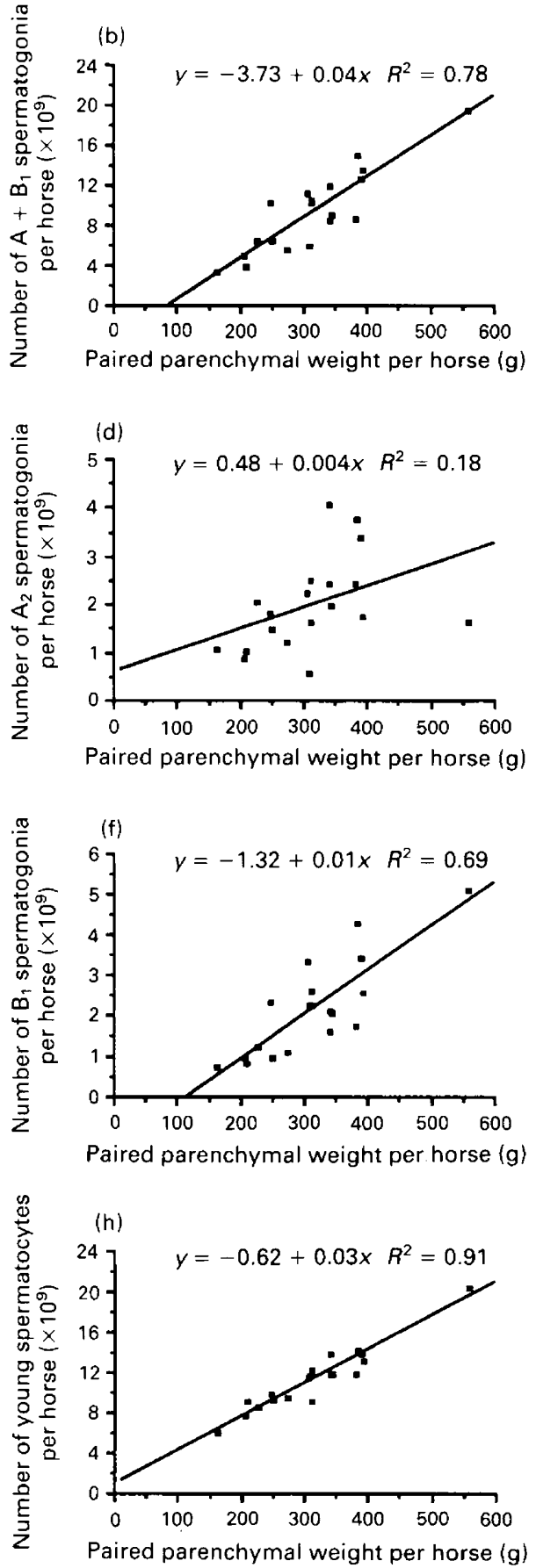

Fig. 3. The effect of parenchymal weight per horse in a subset of 19 horses representing both the breeding and nonbreeding seasons on (a) daily sperm production per horse and on the number per horse of (b) all $A$ plus $B_{1}$ spermatogonia, (c) $A_{1}$ spermatogonia, (d) $A_{2}$ spermatogonia, (e) $A_{3}$ spermatogonia, (f) $B_{1}$ spermatogonia, (g) $B_{2}$ spermatogonia, and (h) young primary spermatocytes. The $R^{2}$ value on each graph reveals the percentage of the variation in parenchymal weight that is attributed to variation in daily sperm production or number of each germ cell. Correlation coefficients ((a) $r=0.902$, (b) $r=0.884$, (c) $r=0.675$, (e) $r=0.840$, (f) $r=0.829,(\mathrm{~g}) r=0.767$ and $(\mathrm{h}) r=0.952)$ are significant $(P<0.01)$. The correlation coefficient between (d) parenchymal weight and number of $\mathrm{A}_{2}$ spermatogonia is not significant $(P>0.05)$.

In horses, it is difficult to calculate precisely the amount of loss that occurs from degeneration during spermatocytogenesis; however, seasonal differences have been detected in the different spermatogonial subtypes that degenerated with a greater yield early and reduced yield late in spermatocytogenesis in the breeding season (Johnson, 1991a). Losses in 
potential sperm production have been estimated at $25 \%$ in mice (Oakberg, 1956), $11 \%$ in Sherman rats (Clermont, 1962), and $75 \%$ in adult Sprague-Dawley rats (Huckins, 1978). Ortavant (1958) found greater degeneration of spermatogonia in rams following long-day illumination characteristic of the nonbreeding season in that species. While the absolute amount of degeneration during spermatocytogenesis is unknown in humans, the amount of degeneration and specific type of spermatogonia that degenerates are not influenced by age (Johnson, 1986).

Bardin (1988) summarized reports noting that the proliferation rate of Sertoli cells in neonatal rats was important in determining testicular size and number of germinal elements in adults. The relationship between number of Sertoli cells and the number of spermatogonia is consistent with our previous findings in younger horses (Johnson et al., 1991b) and are consistent with the findings that the relationship between number of Sertoli cells and daily sperm production could be traced to the number of type A spermatogonia (Johnson, 1985). Although correlations have not been reported in the context of identifying the origin (within spermatocytogenesis) of the relationship between sperm production rates and numbers of Sertoli cells in horses, seasonal variation in the number of spermatogonia has been found (Johnson, 1991a). Seasonal variation in the number of renewing stem cells has been found in rams and red deer stags, and there is a relationship between the number of $A_{1}$ stem cell spermatogonia and the number of Sertoli cells in the ram (Hochereau-de-Reviers, 1981). Studies reporting ratios of germ cells per Sertoli cell in the horse (Johnson and Thompson, 1983; Johnson, 1986; Berndtson and Jones, 1989) or other studies in which the number of Sertoli cells in the horse were determined (Johnson and Nguyen, 1986; Jones and Berndtson, 1986; Russell et al., 1990) have not quantified specific subtypes of spermatogonia for comparison with number of Sertoli cells. Sertoli cells are generally assumed to have a stable population size in adults (Hochereau-deReviers and Courot, 1978; Jones and Berndtson, 1986; Sinha Hikim et al., 1988; Russell et al., 1990) because evidence of Sertoli cell division and Sertoli cell death is not obvious in adults. However, the age-related loss of Sertoli cells in humans (Johnson et al., 1984) was not accompanied by obvious degeneration of Sertoli cells, and mitotic activity at the base of seminiferous epithelium is generally considered only spermatogonial in nature.

On the basis of four different groups of horses, we conclude that the number of Sertoli cells are not stable in adult horses. In the first group of 20 horses, aged $4-5$ years, it was found that the Sertoli cell population was $48 \%(P<0.05)$ greater in the middle of the breeding season than at the onset of the breeding season (Johnson and Thompson, 1983). In the same horses, the length of seminiferous tubules increased from $1.9 \pm 1.0 \mathrm{Km}$ at the onset to $2.9 \pm 0.3 \mathrm{Km}(P<0.01)$ in the middle of the breeding season, yet tubular diameter, size of Sertoli cell nuclei and the number of Sertoli cells per tubular cross-section were similar during the same period. In the second group of 201 horses aged 6 months to 20 years, number of Sertoli cells per horse increased by $36 \%$ in the breeding season (summer) over the nonbreeding season (winter; Johnson and Thompson, 1983). The third group of 184 different horses has been used to reveal trimonthly (Johnson and Nguyen, 1986) or monthly
(Johnson and Tatum, 1989) differences in numbers of Sertoli cells throughout the year. In the fourth group composed of 123 horses aged 1-5 years, it was found that the number of Sertoli cells was greater $(P<0.05)$ in the breeding season even in these young horses (Johnson et al, 1991b).

The obvious lack of a stable population of Sertoli cells in horses may have implications for other species. To confirm that the number of Sertoli cells per testis was not stable in adult horses, and to circumvent assumptions made for a given stereological approach to quantify Sertoli cells, we used five different stereological approaches to determine the number of Sertoli cells in the nonbreeding and breeding seasons. These were discussed in detail by Johnson et al. (1991b). Although others have quantified Sertoli cells in other seasonal breeders (Hochereau-de-Reviers and Courot, 1978; Sinha Hikim et al., 1988) or in horses in the breeding season (Jones and Berndtson, 1986; Berndtson and Jones, 1989; Russell et al., 1990), to our knowledge, no other investigators have evaluated the effect of season on the number of Sertoli cells in horses. Indeed, the age-related reduction in numbers of Sertoli cells in humans (Johnson et al., 1984) may be a net loss in the turnover of a larger percentage of cells.

Evaluation of the impact of stem cell spermatogonia on seasonal differences in spermatogenesis or the relationship of these cells to other testicular cell populations is complicated by our failure to understand the relationship between histologically distinguishable spermatogonia and different generations of spermatogonial subtypes, as well as our lack of knowledge of the lifespans of the given subtypes in horses (Johnson, 1991a). Further, $A_{1}$ or $A_{2}$ spermatogonia potentially present more than one generation of spermatogonia. Although $A_{I}$ possibly represents the stem cell, it probably represents the committed aligned spermatogonia (Amann, 1989; Johnson, 1987, 1991b) described by Huckins (1971) in rats. Intercellular abridges between adjacent $A_{I}$ spermatogonia connect as many as six cells (Johnson, 1991a). Confirmation of any stem cell renewal model is difficult, if not impossible. Even in rats, in which spermatocytogenesis has been studied most thoroughly, the stem cell has been attributed to every subtype of spermatogonia $\left(A_{1}, A_{2}, A_{3}, A_{4}\right.$ or $\left.A_{5}\right)$ other than $B$ spermatogonia (Huckins, 1971).

Seasonal modulation of the number of A spermatogonia in a species results from proliferation and yield of renewing stem cells (Hochereau-de-Reviers, 1981), and both number of $A_{1}$ spermatogonia and their yield are important in regulating spermatogenesis in horses (Johnson, 1985, 1991a). Stem cell spermatogonia are the earliest (most primitive) form of germ cells, which may be dormant (reserve) in testes active in spermatogenesis ( $A_{0}$ stem cell; Clermont and Bustos-Obregon, 1968) or actively involved in the production of other stem cells or proliferating spermatogonia $\left(A_{s}\right.$ stem cell; Huckins, 1971). In any event, these cells carry on the lineage throughout the life of adult males. It is not clear whether $A_{1}$ spermatogonia are the equine stem cells; however, their numbers are very important in the relationship between Sertoli cell number or parenchymal weight and daily sperm production in horses. This finding is a first step to direct further studies to the causative factors that enhance the numbers of $A_{I}$ spermatogonia and Sertoli cells to eliminate seasonality in horses and enhance spermatogenesis in general. 
Special thanks are extended to Beltex Corporation, 3801 North Grove, Fort Worth, Texas, for kindly providing horse tissues, to H. B. Nguyen and M. Barletta for providing excellent technical assistance, and to V. Marsh for typing and providing editorial assistance. This work was supported in part by NIH Grant HD-16773 and a Research Enhancement Grant from the Institute for Equine Science and Technology at Texas A\&M University and Texas Agricultural Experiment Station.

\section{References}

Amann RP (1989) Spermatogenesis. In Management of the Stallion for Maximum Reproductive Efficiency, Vol. II pp 27-37 Eds BW Pickett, RP Amann, AO McKinnon, EL Squires and JV Voss. Colorado State University, Fort Collins

Bardin CW (1988) The Sertoli cell. In The Physiology of Reproduction, Vol. I PP 933-975 Eds E Knobil and JD Neill. Raven Press, New York

Berndtson WE and Jones LS (1989) Relationship of intratesticular testosterone content of stallions to age, spermatogenesis, Sertoli cell distribution and germ cell-Sertoli cell ratios Journal of Reproduction and Fertility 85 511-518

Chalkley HW (1943) Method for the quantitative morphologic analysis of tissues Journal of National Cancer Institute 4 47-53

Clermont Y (1962) Quantitative analysis of spermatogenesis of the rat: a revised model for the renewal of spermatogonia American journal of Anatomy 111 111-129

Clermont $Y$ and Bustos-Obregon $E$ (1968) Re-examination of spermatogonial renewal in the rat by means of seminiferous tubules mounted in toto American Journal of Anatomy 122 237-248

Feig LA, Bellvé AR, Erickson NH and Klagsbrun M (1980) Sertoli cells contain a mitogenic polypeptide Proceedings National Academy of Sciences USA 77 $4774-4778$

Hochereau-de-Reviers MT (1981) Control of spermatogonial multiplication. In Reproductive Processes and Contraception, pp 307-331 Ed. KW McKerns. Plenum Press, New York

Hochereau-de-Reviers MT and Courot M (1978) Sertoli cells and development of seminiferous epithelium Annals of Biology and Animal Biochemistry and Biophysics (2B) 18 573-583

Huckins C (1971) The spermatogonial stem cell population in adult rats. I. Their morphology, proliferation and maturation Anatomical Record 169 $533-548$

Huckins C (1978) The morphology and kinetics of spermatogonial degeneration in normal adult rats: an analysis using a simplified classification of the germinal epithelium Anatomical Record 190 905-926

Johnson L (1985) Increased daily sperm production in the breeding season of stallions is explained by an elevated population of spermatogonia Biology of Reproduction 32 1181-1190

Johnson L (1986) Review article: spermatogenesis and aging in the human Journal of Andrology 7 331-354

Johnson L (1987) Effect of season on spermatogenesis in stallions Proceedings of the Annual Meeting of the American Association of Veterinary Anatomists (Abstract) 28 Madison, WI

Johnson L (1991a) Seasonal differences in equine spermatocytogenesis Biology of Reproduction 44 284-291
Johnson L (1991b) Spermatogenesis. In Reproduction in Domestic Animals, (4th Edn) pp 174-215 Ed. PT Cupps. Academic Press, New York

Johnson L and Neaves WB (1981) Age-related changes in the Leydig cell population, seminiferous tubules and sperm production in stallions Biology of Reproduction 24 703-712

Johnson L and Nguyen HB (1986) Annual cycle of Sertoli cell population in adult stallions Journal of Reproduction and Fertility 76 311-316

Johnson L and Tatum ME (1989) Temporal appearance of seasonal changes in numbers of Sertoli cells, Leydig cells, and germ cells in stallions Biology of Reproduction 40 994-999

Johnson L and Thompson DL, Jr (1983) Age-related and seasonal variation in the Sertoli cell population, daily sperm production and serum concentrations of follicle-stimulating hormone, luteinizing hormone and testosterone in stallions Biology of Reproduction 29 777-789

Johnson $\mathbf{L}$ and Thompson DL, Jr (1986) Seasonal variation in the total volume of Leydig cells in stallions is explained by variation in cell number rather than cell size Biology of Reproduction $35971-979$

Johuson L, Zane RS, Petty CS and Neaves WB (1984) Quantification of the human Sertoli cell population: its distribution, relation to germ cell numbers, and age-related decline Biology of Reproduction 31 785-795

Johnson L, Varner DD, Tatum ME and Scrutchfield WL (1991a) Season but not age affects Sertoli cell number in adult stallions Biology of Reproduction 45 404-410

Johnson L, Varner DD and Thompson DL, Jr (1991b) Effect of age and season on the establishment of spermatogenesis in the horse Joumal of Reproduction and Fertility 44 87-97

Jones, LS and Berndtson WE (1986) A quantitative study of Sertoli cell and germ cell populations as related to sexual development and aging in the stallion Biology of Reproduction 35 138-148

Oakberg EF (1956) A description of spermiogenesis in the mouse and its use in analysis of the cycle of the seminiferous epithelium and germ cell renewal American Joumal of Anatomy 99 391-413

Ortavant R (1958) Le cycle spermatogenietuque chez le Belier. D.Sc. Thesis, University of Paris

Russell LD, Ping Ren H, Sinha Hikim I, Schulze W and Sinha Hikim AP (1990) A comparative study in twelve mammalian species of volume densities, volumes and numerical densities of selected testes components, emphasizing those related to the Sertoli cell American Joumal of Anatomy 188 20-21

Sinha Hikim A, Bartke A and Russell LD (1988) Morphometric studies on hamster testes in gonadally active and inactive states: light microscope findings Biology of Reproduction 39 1225-1237

Sokal RR and Rohlf FJ (1969) Biometry. pp 220-508. WH Freeman and Co., San Francisco

Swierstra EE, Gebauer MR and Pickett BW (1974) Reproductive physiology of the stallion. I. Spermatogenesis and testis composition Journal of Reproduction and Fertility 40 113-123

Thompson DL, Jr, Pickett BW, Berndtson WE, Voss JL and Nett TM (1977) Reproductive physiology of the stallion: VIII Artificial photoperiod, collection interval and seminal characteristics, sexual behavior and concentration of LH and testosterone in serum Journal of Animal Science 44 656-664

Weibel ER and Paumgartner D (1978) Integrated stereological and biochemical studies on hepatocytic membranes. II. Correction of section thickness effect on volume and surface density estimates Journal of Cell Biology 77 584-597 